\title{
Use of Algae as Fish Feed and their Impact on Fish Immunity
}

\author{
Priyanka Mukherjee* and Ruma Pal \\ Department of Botany, University of Calcutta, India
}

Submission: September 19, 2019; Published: November 01, 2019

Corresponding author: Priyanka Mukherjee, Department of Botany, University of Calcutta, 35 Ballygunge Circular Road, Kolkata- 700019 West Bengal, India

\begin{abstract}
Algae stand out to be one of the rich sources of various primary and secondary metabolites -known as bioactive compounds. In the present review we have discussed about the utilisation of the algae as live or feed supplements for both edible and coloured fish varieties. Their immense effects on fish growth and immunity have also been reviewed here. Being rich sources of carotenoids, the algal diets may be the best one for fish coloration along with increased immunity level. Therefore, incorporation of algae in fish diets has been found to be beneficial in aquaculture practices.
\end{abstract}

Keywords: Algae; Aquaculture; Fish feed; Growth; Coloration; Immunity

\section{Introduction}

Algae in their macro- or micro forms act as hubs of several bioactive compounds which have remained conserved in them through evolutions and helped them to strive through several adverse conditions [1]. These bioactive components are mostly secondary metabolites comprising of phenols, flavones, flavanols, pigments (b-carotene), sulfated polysaccharides and vitamins, which can be used effectively in the feed, pharmaceuticals as well as nutraceutical industries [2,3]. Aquafarming today is one of the most important trades all over the world which earns a huge revenue to the country's economy. This practice of rearing aquatic organisms in controlled conditions for commercial purposes (Aqua culture) dates to $6000 \mathrm{BC}$.

The concept was first developed by Gunditjmara people of Victoria, Australia in the year 1830, where they first converted volcanic floodplains in the vicinity of Lake Condah into complex of channels and dams for capturing eel fish for consumption. Intensive aquaculture is highly dependent on fish oil and fish meal as feed ingredients. Fish meal stands to be essential dietary sources of protein, amino acids, fatty acids etc [4]. The rapid growth of aquaculture has resulted in higher demand for market available fish meal resulting in their high prices which imposes a constant threat for both fish keepers as well as fish breeders. Microalgae play an important role as fish feed ingredients because of their nutritive properties. They induce growth, immunity and colorations in fishes. In this review, we aim to discuss the use of various algae as fish feed and the efficiency of the algae as fish diet.

\section{Algae as Feed Ingredients for Edible and Coloured} Fishes

Edible fish culture includes the rearing and production of different families of fishes out of which Cyprinidae forms the largest family. Throughout the world several hectares of freshwater ponds have been used to rear fishes like catla, mrigal, rohu, tilapia, rainbow trouts etc. Colour fish rearing is also a very common practice because of their high aesthetic values and their ability to survive in an artificial environment. Incorporation of algae in fish diet has been studied by several researchers throughout the world. According to Newman et al [5] the nutritive properties, vibrant pigment profiles and a high content of bioactive compounds with cytostatic, antiviral, anthelmintic, antifungal and antibacterial activities in algae provides health and immunity to the edible as well as ornamental fishes. Different microalgae such as Haematococcus, Dunaliella, Chlorella, Chlorococcum, Ulva, Ascophyllum nodosum, Porphyra, Scenedesmus sp. etc have been found to induce good health in different fishes such as rainbow trout, red porgy, red sea bream, Nile tilapia and in carps when incorporated as live or supplemented feed [6-8]. Similarly, incorporation of microalgae viz., Navicula, Nostoc, Ulva, Cladophora, Chlorella, Haematococcus, Porphyra, Scenedesmus, Chlorella, Sargassum 
have also enhanced skin pigmentation as well as growth performances in different coloured fishes such as tetras, cichlids, goldfish, koi carps, rabbitfish etc [9-12].

\section{Effect of Algae Based Diet on Fish Health and Immunity}

Fish meal stands to be essential dietary sources of protein, amino acids, fatty acids etc [4]. Furthermore, fishes are also highly susceptible to different diseases caused due to biological and non-biological factors during the period of culture. In response to the oxidative stresses the fishes produce certain enzyme systems (superoxide dismutase, catalase, and glutathione peroxidise), functionalized large molecules (albumin, ferritin, and ceruloplasmin) and small molecules (ascorbic acid, a-tocopherol, b-carotene, and uric acid) to combat the ROS production [13]. The fish enzymes and metabolic products therefore stand as valuable indicators for assessing fish health and are reported to be affected by dietary feed additives [14, 15]. Microalgae have high content of pigments about 3-5 \% of dry algal biomass (chlorophyll, $\alpha$ - carotene, $\beta$ - carotene, lutein, lutein 5- 6 epoxide, antheraxanthin, zeaxanthin, violaxanthin, neoxanthin, lycopene, canthaxanthin, astaxanthin), fatty acids, protein, vitamins etc. Amongst all the pigments, carotenoids form the basis of innate immunity, metabolism, reproduction efficiency as well as skin coloration in fishes [16].

Generally, the carotene up taken from algal diet are rapidly converted to astaxanthin in fishes, an effective antioxidant playing a very important role in chelating the free radicals, thereby increasing the resistance of fishes to fungal pathogens. The hepatopancreatic function is also improved by algal pigment incorporation in fish diet which provides protection to the cells against photo-oxidation of polyunsaturated fatty acids and cholesterol content of the organism [17]. Along with the pigment contents, high protein, carbohydrate, fatty acid and vitamin contents of algae are directly proportional to the nutrient levels of the fish feed. The algal feed supplementation improves the morphometric nature as well as useful fatty acid profiles in fishes. Khatoon et al. [11] have showed enhancement of skin pigmentation and growth in goldfish on application of fresh algal biomass of Nostoc ellipsosporum and Navicula minima in algae-based value-added feed (VAF). Mukherjee et al. [12] also observed that a mixture of cyanobacteria enhanced pigmentation in four types of ornamental fishes. Furthermore, minimum stress enzyme accumulation along with less mortality rate were observed in case of goldfish and carps on being fed on mixed algal diet in experiments conducted by the present group [18].

\section{Conclusion}

Therefore, from the review it can be concluded that the green, brown and red algae are rich sources of bioactive compounds for their high content of primary and secondary metabolites. Due to presence of numerous promising and remarkable biologically active molecules algae have immense effects in the field of aquaculture.

\section{References}

1. Kumar S, Ganesan K, Subba Rao PV (2007) Phycoremediation of heavy metals by the three-color forms of Kappaphycus alvarezii. Journal of Hazardous Materials 143(1-2): 590-592.

2. Borowitzka MA, Borowitzka LJ (1988) Micro-algal biotechnology. In: Cambridge University Press, Cambridge, P. 96-100.

3. Shibata T, Yamaguchi K, Nagayama K, Kawagushi S, Nakamura T (2002) Inhibitory activity of brown algal phlorotannins against glycosidases from the viscera of the turban shell $\mathrm{T}$ cornutus. European Journal of Phycology 37: 493-500.

4. Tacon AGJ (1993) Feed ingredients for warm water fish: Fish meal and other processed feedstuffs. FAO Fisheries Circular 64: 856.

5. Newman DJ, Cragg GM, Snader KM (2003) Natural products as source of new drugs over the period 1981-2002. J Nat Prod 66: 1022-1037.

6. Norambuena F, Hermon K, Skrzypczyk V, Emery JA, Sharon Y, et al. (2015) Algae in fish feed: performances and fatty acid metabolism in juvenile atlantic salmon. Plos One 10(4): e0124042.

7. Sheikhzadeh N, Hossein TN, Oushani AK, Hamed M, Enferadi N (2012) Effects of Haematococcus pluvialis supplementation on antioxidant system and metabolism in rainbow trout (Oncorhynchus mykiss). Fish Physiol and Biochem 38: 413-419.

8. Tartiel M, Badwy E, Ibrahim M, Zeinhom MM (2008) Partial replacement of fish meal with dried microalga (Chlorella spp and Scenedesmus spp) In Nile Tilapia (Oreochromis niloticus) Diets. 8th International Symposium on Tilapia in Aquaculture 801-811.

9. Gouveia L, Gomes E, Empis J (1998) Use of Chlorella vulgaris in diets for rainbow trout to enhance pigmentation of muscle. Journal of Applied Aquaculture 77: 61-70.

10. Guroy BK, Cirik S, Guroy D, Sanver F, Tekinay AA (2007) Effects of Ulva rigida and Cystoseira barbata meals as a feed additive on growth performance, feed utilization and body composition of Nile Tilapia, Oreochromis niloticus. Turkish Journal of Veterinary Animal Science 31(2): 91-97.

11. Khatoon N, Sengupta P, Homechaudhuri S, Pal R (2010a) Evaluation of algae-based feed in Goldfish (Carassius auratus) nutrition. Proceedings of Zoological Society 63 (2): 109-114.

12. Mukherjee P, Nandi C, Khatoon N, Pal R (2015) Mixed algal diet for skin colour enhancement of ornamental fishes. Journal of Algal Biomass Utilisation 6(4): 35-46.

13. Martinez-Alvarez RM, Morales AE, Sanz A (2005) Antioxidant defenses in fish: biotic and abiotic factors. Review of Fish Biology 15: 75-88.

14. Welker TL, Congleton JL (2009) Effect of dietary a-tocopherol ? ascorbic acid, selenium, and iron on oxidative stress in sub-yearling Chinook salmon (Oncorhynchus tshawytscha Walbaum). Journal of Animal Physiology and Animal Nutrition 93: 15-25.

15. Wu G, Yuan C, Shen M, Tang J, Gong Y, Li D, et al. (2007) Immunological and biochemical parameters in carp (Cyprinus carpio) after Qompsell feed ingredients for long-term administration. Aquaculture Research 38: 246-255.

16. Mukherjee A, Mandal B, Banerjee S (2009) Turmeric as a Carotenoid Source on Pigmentation and Growth of fantail guppy, Poecilia reticulate. Proceedings of Zoological Society 62 (2): 119-123.

17. Britton G (1995) Structure and properties of carotenoids in relation to function. FASEB J 9: 1551-1558. 
18. Mukherjee P, Gorain P C, Paul I, Bose R, Bhadoria P B S, et al. (2019) Investigation on the effects of nitrate and salinity stress on the antioxidant properties of green algae with special reference to the use of processed biomass as potent fish feed ingredient. Aquaculture International 1-24.

Your next submission with Juniper Publishers will reach you the below assets

- Quality Editorial service

- Swift Peer Review

- Reprints availability

- E-prints Service

- Manuscript Podcast for convenient understanding

- Global attainment for your research

- Manuscript accessibility in different formats

( Pdf, E-pub, Full Text, Audio)

- Unceasing customer service

Track the below URL for one-step submission

https://juniperpublishers.com/online-submission.php 